15

\title{
Получение гибкого электрода из графена и малослойного графита
}

\author{
(C) Х.А. Абдуллин, ${ }^{1}$ Е.В. Чихрай, ${ }^{2}$ М.Т. Габдуллин, ${ }^{1}$ Д.В. Исмаилов ${ }^{1, \text { ฯ }}$ \\ ${ }^{1}$ Национальная нанотехнологическая лаборатория открытого типа (ННЛОТ), \\ Казахский национальный университет им. аль-Фараби, \\ 050012 Алматы, Казахстан \\ ${ }^{2}$ Научно-исследовательский институт экспериментальной и теоретической фризики (НИИЭТФ), \\ Казахский национальный университет им. аль-Фараби, \\ 050012 Алматы, Казахстан \\ ฯ e-mail: ismailov_daniyar_v@bk.ru
}

(Поступило в Редакцию 7 июня 2017 г. В окончательной редакции 13 февраля 2018 г.)

Описан метод получения оксида графена из чешуйчатого серебристого графита модифицированным методом Хаммерса с последующим получением восстановленного графена и малослойного графита. Исследованы структура и электрические свойства полученного материала. На примере подложек на основе полиэтилена с нанесенным слоем проводящей краски показана возможность получения гибкого электрода с высокой емкостью.

DOI: $10.21883 / J T F .2018 .07 .46190 .2378$

\section{Введение}

Углеродные наноструктурированные материалы, такие как графен и малослойный графит, обладают уникальными свойствами: высокая удельная поверхность, высокая электропроводность, химическая стойкость. Благодаря этому они находят широкое практическое применение для создания химических источников тока, топливных элементов и суперконденсаторов [1-3], проводящих и гибких электродов с высокой удельной площадью [4-6], сенсоров и гетероструктур [7,8]. Стоимость углеродных наноструктурированных материалов пока еще достаточно высока, поэтому разработка низкозатратных методов их получения весьма актуальна. В настоящей работе приведены результаты по получению графена и малослойного графита, гибких электродов на его основе из недорогого исходного материала — чешуйчатого серебристого графита, имеющего низкую стоимость и доступного на рынке.

\section{Методика эксперимента}

Оксид графита синтезировали из чешуйчатого графита модифицированным методом Хаммерса [9]. Вкратце метод состоял в следующем: порошок графита (1 $\mathrm{g})$ добавлялся в смесь концентрированной серной кислоты $(90 \mathrm{ml})$ и ортофосфорной кислоты $(10 \mathrm{ml})$ и размешивался на магнитной мешалке без нагрева. Затем медленно добавлялся порошок $\mathrm{KMnO}_{4}(6 \mathrm{~g})$ при непрерывном перемешивании на магнитной мешалке, при этом начиналось выделение тепла за счет проходящих реакций. Температура раствора контролировалась и не поднималась выше $310 \mathrm{~K}$ путем регулирования скорости подачи порошка $\mathrm{KMnO}_{4}$. Как только реакция замедлялась и температура начинала падать, включался нагрев магнитной мешалки для поддержания температуры при $320 \mathrm{~K}$. При этом проводилось непрерывное размешивание в течение $24 \mathrm{~h}$.

Для прекращения реакции окисления графита раствор выливался на лед, состоящий из $250 \mathrm{ml}$ воды и $10 \mathrm{ml} \mathrm{30 \%} \mathrm{перекиси} \mathrm{водорода,} \mathrm{цвет} \mathrm{раствора} \mathrm{менялся}$ от коричневого до зеленого. После центрифугирования получена коричневая суспензия, которую промывали в соляной кислоте для удаления ионов металлов, а затем несколько раз чередовали промывку в воде и центрифугирование в течение $60 \mathrm{~min}$ при $4000 \mathrm{rpm}$ для достижения нейтрального раствора с $\mathrm{pH}=6$. После обработки в ультразвуковой ванне в течение нескольких часов получен темно-коричневый раствор оксида графена (GO, graphene oxide) с концентрацией $\sim 1 \mathrm{mg} / \mathrm{ml}$, который оставался стабильным на протяжении нескольких месяцев.

Для исследований методами рентгеновской дифракции, электросопротивления, рамановской спектроскопии раствор GO наносился на поверхность стеклянной подложки размерами $76 \times 25 \mathrm{~mm}$, предварительно обработанной в водном растворе аммиака и перекиси водорода для создания гидрофильной поверхности. Подложка высушивалась при комнатной температуре, затем разрезалась на несколько образцов для дальнейших исследований.

Структура пленок GO исследована методом широкоугловой рентгеновской дифракции с помощью дифрактометра X'pert PRO MPD (PANalytical). Электрическое сопротивление образцов определялось с помощью электрометра Keithley Instruments 6517В четырехзондовым методом. Спектры рамановского рассеяния образцов исследованы с помощью спектрометра NTegra Spectra (NT-MDT). Измерения циклической вольтамперометрии и гальваностатические измерения заряда/разряда проводились с помощью потенциостата Elins P-30J. 


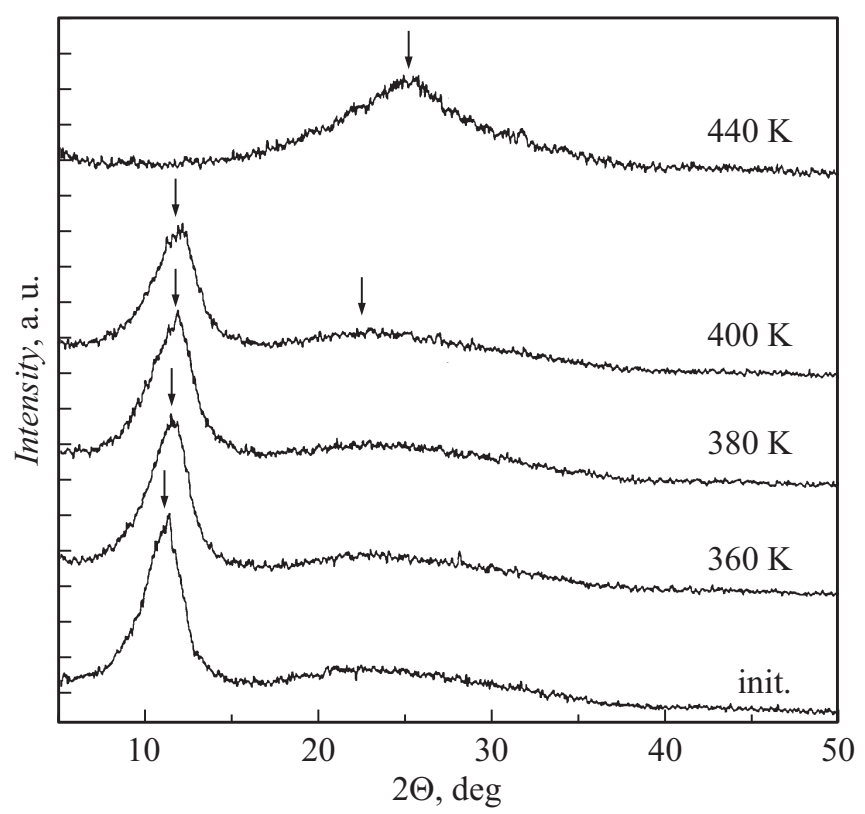

Рис. 1. Дифрактограммы исходного образца GO и после отжига при температурах $360-440 \mathrm{~K}$ на воздухе в течение $30 \mathrm{~min}$.

\section{Результаты и обсуждение}

На рис. 1 показаны дифрактограммы пленок GO. Основной рефлекс в исходном образце расположен при угле $2 \Theta \sim 10.6^{\circ}$, что соответствует межслоевому расстоянию $d(002) \sim 0.83 \mathrm{~nm}$. Известно, что межслоевое расстояние $d(002)$ в оксиде графена пропорционально степени окисления [9]. Поэтому результаты рентгеновской дифракции (XRD) свидетельствуют о высокой степени общего окисления в полученных образцах. Наблюдалось увеличение угла дифракции $2 \Theta$ до $\sim 12^{\circ}$ при росте температуры отжига до $400 \mathrm{~K}$, что соответствует уменьшению межслоевого расстояния до $0.735 \mathrm{~nm}$.

В дифрактограммах пленок GO также наблюдается широкая полоса с низкой интенсивностью при углах $2 \Theta \sim 22^{\circ}$, характерная для образцов малослойного графена (few-layer graphene), в которых отсутствует дальний порядок в направлении, перпендикулярном графеновым плоскостям.

Отжиг выше $420 \mathrm{~K}$ приводил к формированию восстановленного оксида графена $(r-\mathrm{GO})$, о чем свидетельствует резкое уменьшение межслоевого расстояния до $0.355 \mathrm{~nm}$, одновременно падало электрическое сопротивление слоев. На рис. 2 показана зависимость электрического сопротивления образцов GO от температуры отжига, на вставке приведен рамановский спектр образца. Электрическое сопротивление измерялось четырехзондовым методом при расстоянии между зондами $2 \mathrm{~mm}$. Как видно из рис. 2, электрическое сопротивление пленки GO резко падает при температуре отжига $420-470 \mathrm{~K}$, что связано с формированием восстановленного оксида графена и хорошо коррелирует c XRD-данными.

На вставке к рис. 2 приведен спектр рамановского рассеяния исходного образца $\mathrm{GO}$, измеренный при возбуждении синим лазером с длиной волны $473 \mathrm{~nm}$. Спектры рамановского рассеяния являются типичными для образцов GO и очень близки к приведенным в литературе спектрам [9]. Форма спектров менялась незначительно при термическом отжиге, отношение интенсивности полос $G$ и $D\left(I_{G} / I_{D}\right)$ росло от 1.247 для исходного образца GO до 1.377 для образца после отжига при $520 \mathrm{~K}$.

Циклическая вольтамперометрия и гальваностатические измерения заряда/разряда проводились в трехэлектродной схеме с платиновым вспомогательным электродом и хлорсеребряным электродом сравнения. Емкость электрода измерялась в диапазоне потенциалов от 0 до $0.6 \mathrm{~V}$. В качестве рабочего электрода использована полиэтиленовая пленка с нанесенным тонким слоем проводящей краски на водной основе, на которую наносилась суспензия оксида графена, восстановленного путем гидротермальной обработки при $420 \mathrm{~K}$ в автоклаве. Определенное количество $r$ - GO наносились на подложку, которая затем сушилась при комнатной температуре. Процесс сушки играет важную роль в получении высокой и стабильной емкости. Обнаружено, что наилучшие результаты получаются, когда оксид графена наносится на не полностью высохшую графитовую краску. Были получены гибкие проводящие электроды, не меняющие своих характеристик при многократных сгибаниях.

На рис. 3 приведены вольт-амперные характеристики графитового электрода при различной скорости развертки по напряжению, снятые в электролите $3 \mathrm{M} \mathrm{KCl}$. Напряжение измерялось относительно хлорсеребряного

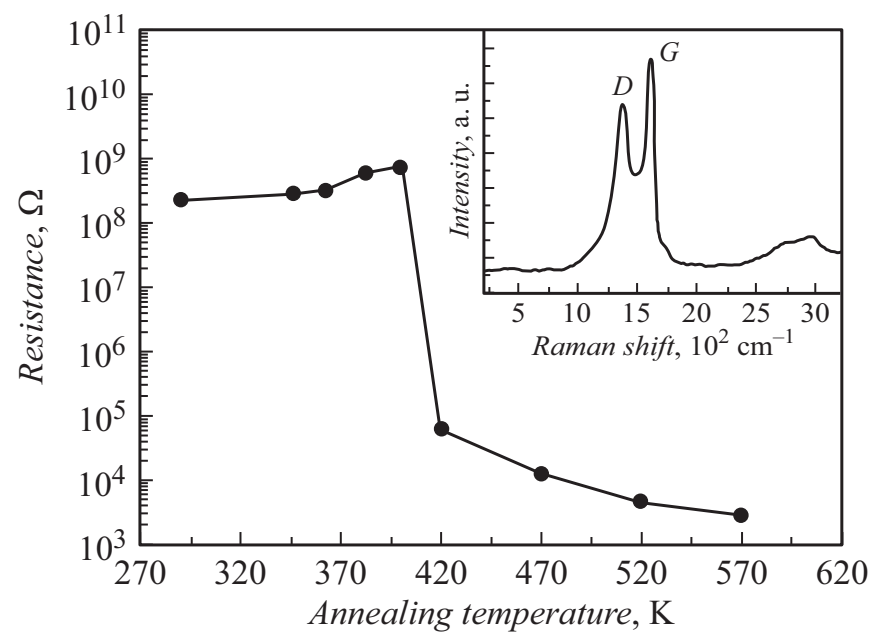

Рис. 2. Зависимость электрического сопротивления образцов GO от температуры изохронного (30 min) отжига на воздухе. На вставке - спектр рамановского рассеяния исходного образца. 

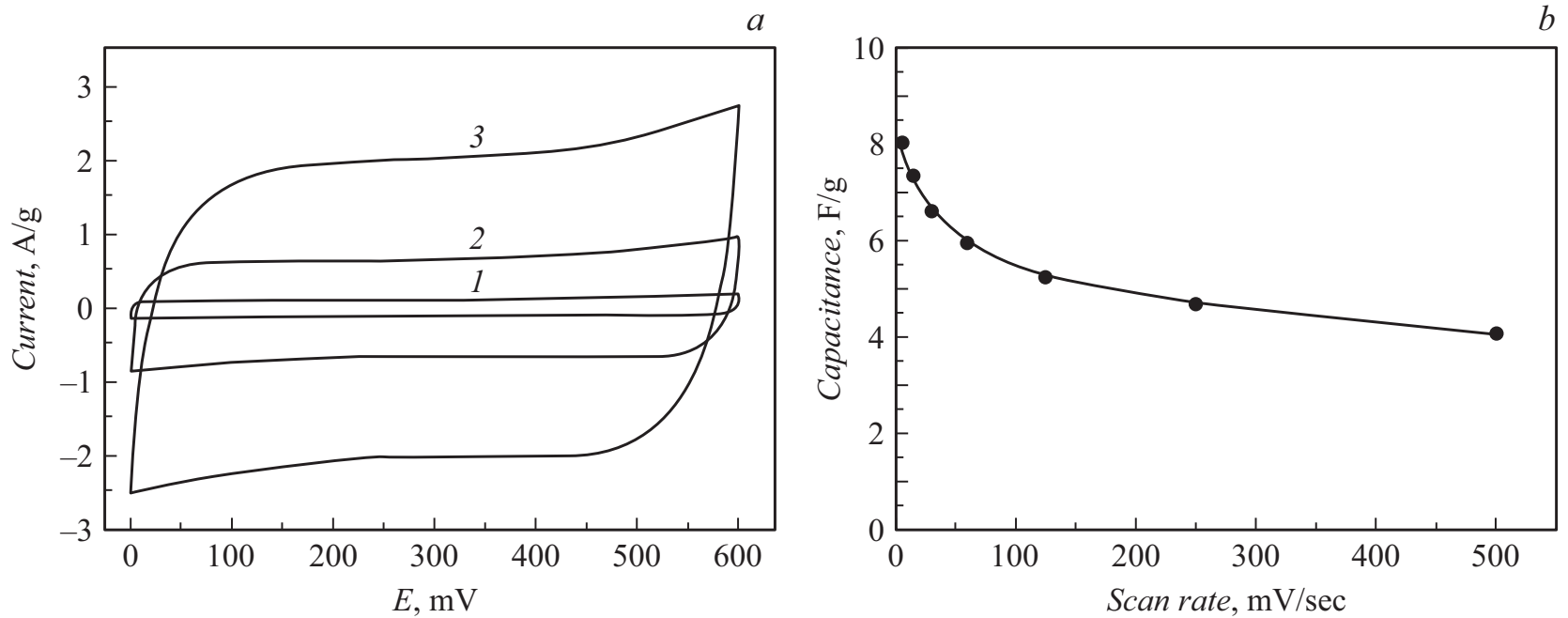

Рис. 3. $a-$ вольт-амперные характеристики графитового электрода из $r$-GO при различной скорости развертки по напряжению: $1-15,2-125,3-500 \mathrm{mV} / \mathrm{s} ; b-$ зависимость емкости от скорости изменения напряжения.

электрода сравнения. Зависимость емкости от скорости изменения напряжения показывает небольшой резистивный вклад в комплексное сопротивление электрода. Достигнута емкость около $8 \mathrm{~F} / \mathrm{g}$.

\section{Заключение}

Таким образом, отработана методика получения оксида графита и малослойного графита из недорогого и доступного исходного материала - чешуйчатого серебристого графита, имеющего стоимость около 1 Euro/kg против стоимости графитовых хлопьев от $25 \mathrm{Euro} / \mathrm{kg}$ и более в зависимости от чистоты материала. Получены углеродные наноматериалы на основе графена и малослойного графита с высокой удельной поверхностью и высокой электропроводностью. Разработан простой способ изготовления из полученного материала гибкого электрода с высокой емкостью. Полученные электроды характеризуются высокой гибкостью и имеют весьма стабильные свойства.

Работа выполнена по гранту АР05130100 Министерства образования и науки Республики Казахстан.

\section{Список литературы}

[1] Bonaccorso F., Colombo L., Yu G. et al. // Science. 2015. Vol. 347. P. 1246501. DOI: $10.1126 /$ science. 1246501

[2] El-Kady M.F., Shao Yuanlong, Kaner R.B. // Nature Rev. Mater. 2016. Vol. 1. N 16033.

[3] Liyi Li, Bo Song, Maurer L. et al. // Nano Energy. http://dx.doi.org/10.1016/j.nanoen.2016.01.028

[4] Jian Li, Xiaoqian Cheng, Sun J. et al. // J. Appl. Phys. 2014. Vol. 115. P. 16430. DOI: $10.1063 / 1.4871290$

[5] Антонова И.В., Котин И.А., Попов В.И. и др. // ФТП. 2016. Т. 50. Вып. 8. С. 1086-1094.
[6] Jiali Yu, Mei Wang, Ping Xu et al. // Carbon. 2017. Vol. 119. P. 332-338.

[7] Лебедев А.А., Лебедев С.П., Новиков С.Н. и др. // ЖТФ. 2016. Т. 86. Вып. 3. С. 135-139.

[8] Антонова И.В. // ФТП. 2016. Т. 50. Вып. 1. С. 67-82.

[9] Marcano D.C., Kosynkin D.V., Berlin J.M. et al. // ACS Nano. 2010. Vol. 4. N 8. P. 4806-4814. 